\title{
Climate change on the forecasted risk of bovine fasciolosis in Espírito Santo state, Brazil
}

\section{Mudanças climáticas e a previsão de risco futuro para fasciolose bovina no estado do Espírito Santo, Brasil}

\author{
Deivid França Freitas ${ }^{1}$; Isabella Vilhena Freire Martins ${ }^{2 *}$; \\ Gleissy Mary Amaral Dino Alves dos Santos ${ }^{3}$; Alexandre Rosa dos Santos ${ }^{4}$
}

\begin{abstract}
The climate change expected for the coming years can cause large economic losses and a strong impact on intestinal parasites of ruminants throughout the world. In this sense, organisms belonging to the class trematoda seem to be highly sensitive to any changes in the patterns of temperature and rainfall caused by possible climate change. So, maps were elaborated forecasting current and future risk to Fasciola hepatica in the state of Espírito Santo, Southeast of Brazil, using as a base increases in the temperature ranging from $1{ }^{\circ} \mathrm{C}$ to $5^{\circ} \mathrm{C}$. Environmental and climatic factors like temperature, rainfall, altitude and declivity were used for generation of maps bioclimatic risk of fasciolosis through of the ArcGIS/ArcInfo 10.1 Software. High-risk areas resulted in a total of $35.42 \%$ for the current risk and tended to decrease with increases in temperature over the next 100 years, which favored a reduction of $35.42 \%$ to $33.84 \%$ in these regions. The places included in the of low risk areas showed significant increases in their areas for temperatures up to $5^{\circ} \mathrm{C}$ with values ranging from $24.65 \%$ to $28.26 \%$ of their areas. These forecasting models using increases in temperatures in the generation of risk maps to $F$. hepatica were first made in Brazil and like the others, represented a tendency to aid in policy making animal and human health oriented regions shown to be potentially suitable for the risk of bovine fasciolosis.
\end{abstract}

Key words: Geographic Information System (GIS), climate change, Fasciola hepatica, cattle

\section{Resumo}

\begin{abstract}
As mudanças climáticas esperadas para os próximos anos podem ocasionar grande impacto sobre as parasitoses intestinais de ruminantes em todo o mundo. Neste sentido, organismos pertencentes à classe Trematoda parecem ser altamente sensíveis a alterações nos padrões de temperatura e precipitação causados por eventuais alterações climáticas. Assim, foram elaborados mapas de previsão de risco atual e futuro para Fasciola hepatica no estado do Espírito Santo, Sudeste do Brasil, utilizando como base o aumentos na temperatura que variaram de $1^{\circ} \mathrm{C}$ a $5^{\circ} \mathrm{C}$. Fatores ambientais e climáticos, como a temperatura, precipitação, a altitude e a declividade foram utilizados para a geração de mapas de risco para fasciolose por meio do programa ArcGIS / ArcInfo 10.1. As áreas de alto risco resultaram em um total de $35,42 \%$ para o risco atual e tenderam a diminuir com o aumento da temperatura para os próximos 100 anos, o que favoreceu uma redução de $35,42 \%$ para $33,84 \%$ nestas regiões. As localidades
\end{abstract}

\footnotetext{
${ }^{1}$ Discente do Programa de Pós Graduação em Biociências e Biotecnologia, Universidade Estadual do Norte Fluminense Darcy Ribeiro, UENF, Campos dos Goytacazes, RJ, Brasil. E-mail: dfnaweb@gmail.com

2 Prof ${ }^{a}$, Programa de Pós-Graduação em Ciências Veterinárias, Universidade Federal do Espírito Santo, UFES, Alegre, ES, Brasil. E-mail: isabella@cca.ufes.br

${ }^{3}$ Discente do Programa de Pós-Graduação em Agroquímica, Universidade Federal de Viçosa, UFV, Viçosa, MG, Brasil. E-mail: gleissym@yahoo.com.br

${ }^{4}$ Prof., Programa de Pós-Graduação em Ciências Florestais, UFES, Alegre, ES, Brasil. E-mail: mundogeomatica@yahoo.com.br

* Author for correspondence
} 
classificadas em baixo risco apresentaram aumentos significativos de suas áreas para temperaturas de até $5^{\circ} \mathrm{C}$, com valores que variaram de $24,65 \%$ a $28,26 \%$ de suas áreas. Estes modelos de previsões utilizando aumentos nas temperaturas na geração de mapas de risco para $F$. hepatica foram as primeiras realizadas no Brasil e, assim como as demais, representaram uma tendência para auxílio na elaboração de políticas de sanidade animal voltadas para as regiões que demonstraram ser potencialmente aptas para o risco da fasciolose bovina.

Palavras-chave: Sistemas de Informações Geográficas (SIG), mudanças climáticas, Fasciola hepatica, bovinos

\section{Introduction}

Fasciolosis is a parasitic disease in Brazil that is mostly caused by the trematode Fasciola hepatica. Cattle and sheep are the main hosts of Fasciola hepatica (SIMSEK et al., 2011), but other domestic animals such as buffaloes, pigs, horses besides humans, may also be susceptible (TUM et al., 2004).

$F$. hepatica is responsible for various economic losses: reduced production of meat, milk, and wool, the disposal of contaminated livers in slaughterhouses, decreased strength and fertility in certain animals and an increased predisposition to other diseases (CUNHA et al., 2007; FOX et al., 2011).

Linked to climatic and environmental factors, the occurrence of fasciolosis is commonly associated with regions with temperatures ranging between 10 and $26{ }^{\circ} \mathrm{C}$ (MITCHELL, 2003). Other variables, such as slope, rainfall and the presence of wetlands, contribute effectively in maintaining aquatic molluscs of the genus Lymnaea, which are the intermediate host for the larval stages of the parasite (DUTRA et al., 2010).

It is known that the distributions of both $F$. hepatica and its intermediate host occur only under adequate conditions of temperature and moisture. In this context, Ollerenshaw and Rowlands (1959) were the first researchers to develop a prediction model for the incidence of Fasciola hepatica based on meteorological data. Since that time, several studies using modeling to predict the incidence $F$. hepatica have been conducted to develop a system for predicting the disease in space and time (HOPECAWDERY et al., 1981; DE WAAL et al., 2007;
KENYON et al., 2009; MAS-COMA et al., 2009; MCCANN et al., 2010; FOX et al., 2011; WALKER et al., 2011; FOX et al., 2012).

Recently, climate change has been identified as a major driver of the increasing prevalence of diseases related to intestinal parasites because their survival depends on a number of environmental and climatological factors (VAN DIJK et al., 2008; FOX et al., 2012). Strong evidence of the links between climatic factors and the occurrence of fasciolosis has led to the creation of predictive models that can help prevent disease incidence on a broader scale, which has enabled the development and implementation of improved control strategies (FOX et al., 2011).

With the development of new technologies, the Geographic Information Systems (GIS) can effectively contribute to the development of spatial risk models for fasciolosis. The GIS can incorporate environmental and climatic data for later correlation with epidemiological data regarding the prevalence of the disease and thus determine the risk factors for its occurrence (MCCANN et al., 2010).

Risk prediction models for fasciolosis have been developed and implemented in African countries (YILMA; MALONE, 1998), Mediterranean countries (KANTZOURA et al., 2011), Australia (DURR et al., 2005), Cambodia (TUM et al., 2004), North America (MALONE et al., 1992; ZUKOWSKI et al., 1993), and South America (FUENTES et al., 2004; FUENTES et al., 2005; FUENTES, 2006; DUTRA et al., 2010).

Thus, in the present study, were developed bioclimatic risk maps for liver fasciolosis in Espírito Santo state in Brazil to forecast the risk using models that simulate gradual temperature increases. 


\section{Materials and Methods}

\section{Study area}

Espírito Santo state, is located from $17^{\circ} 53^{\prime} 29^{\prime \prime}$ to $21^{\circ} 18^{\prime} 03^{\prime \prime}$ south latitude and $39^{\circ} 41^{\prime} 18^{\prime \prime}$ to $41^{\circ} 52^{\prime} 45^{\prime}$ longitude west of Greenwich, and together with the states of Minas Gerais, Rio de Janeiro, and São Paulo (Figure 1), it is part of the Southeastern Region of Brazil. The territory of
Espírito Santo state comprises two distinct natural regions: the coastline, which extends over an area of $400 \mathrm{~km}$, and the plateau. There is a strip of plain along the Atlantic coast that represents $40 \%$ of Espírito Santo state's total area, and going inland, the plateau gives rise to a mountainous region that reaches to the Serra do Caparaó with altitudes above 1000 m (SILVA et al., 2011).

Figure 1. Characterization of the Espírito Santo state, southeastern region of Brazil.

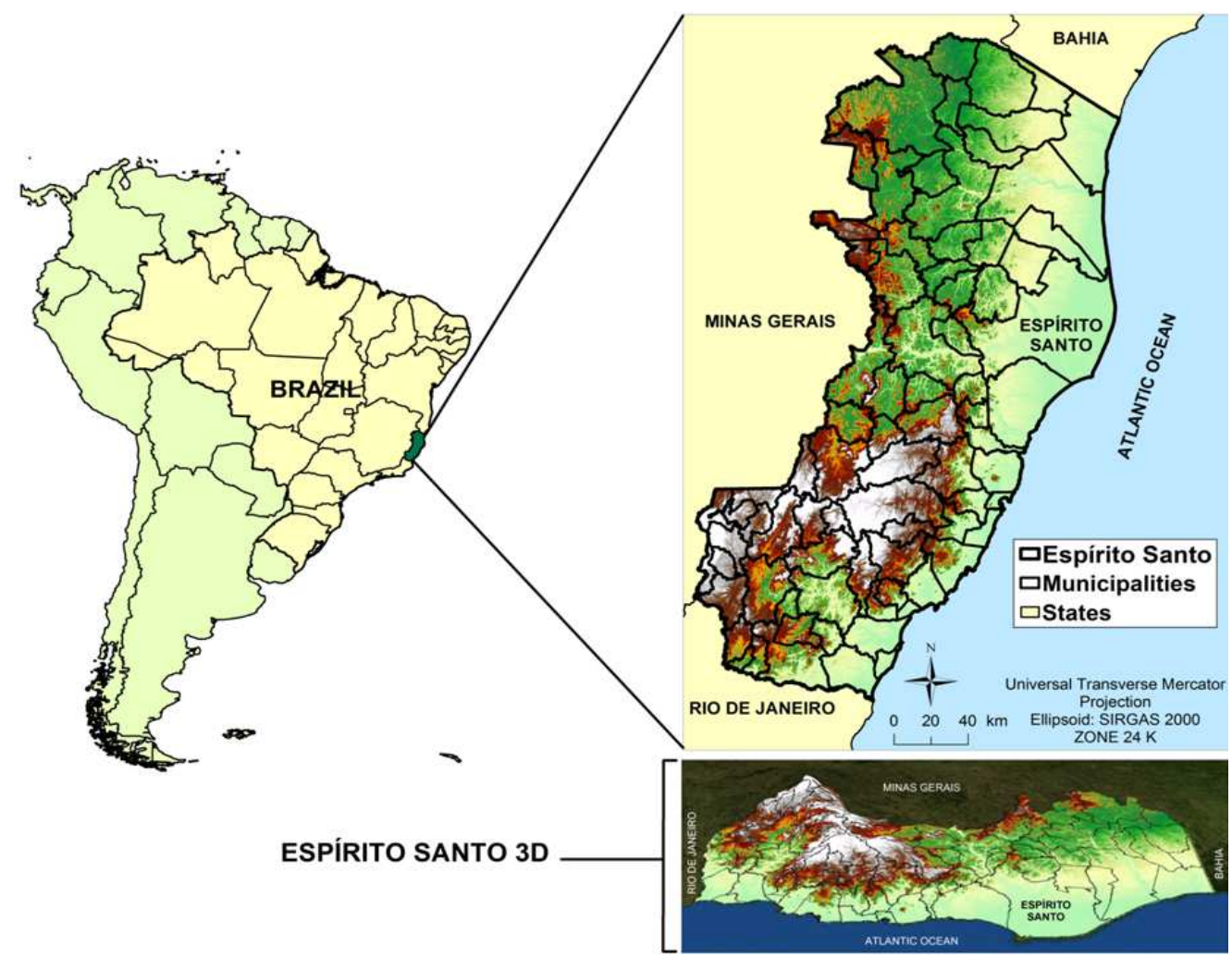

Source: Elaboration of the authors.

Espírito Santo is located in a coastal region, and the state is under pressure from winds, such as the semi-fixed South Atlantic anticyclone and the mobile Polar anticyclone. According to the Köppen classification, the climate is $A w$, i.e., hot and humid (tropical rainy) with rains in the summer and droughts in the winter (sub-dry in August) (VIANELLO; ALVES, 1991).
Determining the factors for fasciolosis in Espirito Santo state, Brazil

For development of zoning maps for fasciolosis in Espirito Santo, were used data from a 30-year time series that represented 110 weather stations that could facilitate statistical data interpolations and the application of the water balance according to Thornthwaite and Matter (1955). 
Using a mathematical model that consisted of GIS data, the variables for predicting the risk factors were entered into a database according to their relevance to the disease. Thus, weights of 1, 2, and 3 (MARTINS et al., 2012) were used to describe the suitable, restrictive, and unfit areas for fasciolosis (Table 1). About the images matrix of altitude, temperature, rainfall and slope, we applied the "reclassification". These values were based on studies that have taken inviable temperatures below $10^{\circ} \mathrm{C}$, restricted between $10{ }^{\circ} \mathrm{C}$ to $15^{\circ} \mathrm{C}$ and higher than $25{ }^{\circ} \mathrm{C}$ and considered optimum in the range from $10{ }^{\circ} \mathrm{C}$ to $26^{\circ} \mathrm{C}$ (MITCHELL, 2003; RAPSCH et al., 2008) as well as favorable as those situated on altitudes from 0 to $500 \mathrm{~m}$ elevation above sea level, and slope values of up to $10 \%$ (TUM et al., 2004; MARTINS et al., 2012). It is known that may be favorable altitudes higher than $1000 \mathrm{~m}$, as case reports of fluke found in the Andean region (MASCOMA et al., 2001), but for this study we chose the one that best represented the track condition site.

Table 1. Attributes and their relative weights according to the potential risk of fasciolosis in Espírito Santo state, Brazil.

\begin{tabular}{cccc}
\hline Variable & & Relative weight & \\
\hline & $1-$ Suitable $^{1}$ & $2-$ Restrictive $^{1}$ & $3-$ Impracticable $^{1}$ \\
\hline Altitude & $0-500 \mathrm{~m}$ & $500-1000 \mathrm{~m}$ & $>1000 \mathrm{~m}$ \\
Temperature & $15-25^{\circ} \mathrm{C}$ & $10-15^{\circ} \mathrm{C}$ and $>25^{\circ} \mathrm{C}$ & $<10^{\circ} \mathrm{C}$ \\
Slope & Until $10 \%$ & 10 to $15 \%$ & Above $15 \%$ \\
Rainfall & $1000-2500 \mathrm{~mm} /$ year & $>1000 \mathrm{~mm} /$ year & $>2500 \mathrm{~mm} /$ year \\
\hline
\end{tabular}

${ }^{1}$ Suitable region (1), restrictive (2) and impracticable (3) possibility for the occurrence of fasciolosis.

Source: Elaboration of the authors.

\section{Bioclimatic risk model}

According to the latest report of the Intergovernmental Panel on Climate Change (IPCC, 2007), it has become evident that the Earth's temperature is rising, and the projections through the end of this century indicate that increases from $1.1^{\circ} \mathrm{C}$ to $6.4^{\circ} \mathrm{C}$ in average air temperatures will occur in various regions worldwide, including Brazil and, consequently, Espírito Santo state. Given these projections and using the water balance that has already been processed, the effects of the following temperature increments were considered in the present study: $+1^{\circ} \mathrm{C},+2^{\circ} \mathrm{C},+3^{\circ} \mathrm{C},+4^{\circ} \mathrm{C}$, and $+5^{\circ} \mathrm{C}$.

\section{Statistical analysis and generating cartographic data}

After the data analysis using the ArcGIS/ ArcINFO 10.1 software, spreadsheets related to the water balance were imported, which resulted in spatial point vectorization of the weather stations and their respective attribute tables. Next, multiple linear regressions were applied to the data set using the altitude and geographical coordinates latitude $(\mathrm{Y})$ and longitude $(\mathrm{X})$ as independent variables and the temperature as the dependent variable, both by the Universal Transverse Mercator (UTM). All of the data were available in the attribute tables from the water balance, which is described in the multiple regression equation below:

$$
T=\beta_{0}+\beta_{1} A L T+\beta_{2} X+\beta_{3} Y
$$

Where:

$\mathrm{T}$ : temperature $\left({ }^{\circ} \mathrm{C}\right)$;

ALT : altitude (m);

$\mathrm{X}: \operatorname{UTM} \mathrm{X}$ coordinate $(\mathrm{m})$;

$\mathrm{Y}: \operatorname{UTM} \mathrm{Y}$ coordinate $(\mathrm{m})$; 
$\beta_{0}$ : regression constant;

$\beta_{1}, \beta_{2}$, and $\beta_{3}$ : Regression coefficients for the ALT, $X$, and $\mathrm{Y}$ variables.

Thus, latitude and longitude matrix images were generated through spatial interpolation using the spherical kriging method. These images were imported into the ArcGIS/ArcINFO 10.1 software, and the Digital Elevation Model (DEM) was generated from the Shuttle Radar Topography Mission (SRTM) project, which was made available by the Brazilian Agricultural Research Corporation at a 1:250,000 scale in a World Geodetic System (WGS) 84 cartographic projection.

For the matrix images of the current and increasing temperatures, we applied the spatial reclassification function with the goal of representing suitable, restrictive, and unfit classes for fasciolosis, and we generated reclassified matrix images for all of the attributes mentioned.

To represent more realistic risk conditions, the data were weighted using the AHP method proposed by Saaty (1977), which prioritized the decisions concerning the problems into levels according to their respective weights. This method synthesized the values of the decision makers, which was a global measure for each alternative, and later prioritized or classified them. Next, were used the decision matrix at the fundamental scale used by Saaty. The method for developing the matrix used a comparison scale that could linearly define the hierarchy of the importance between the previously defined factors an acceptable reason Consistency 0.03 .

After assigning the statistical weights of each of the vectorial polygonal classes, a function "raster calculator" was used to generate the statistical mathematical model for the bioclimatic risk of fasciolosis (BRF) represented by:

$$
B R F=R(R e)+S(R e)+T(R e)
$$

BRF: Bioclimatic risk of fasciolosis

$\mathrm{R}(\mathrm{Re})$ : Rainfall Reclassified

$\mathrm{S}(\mathrm{Re})$ : Slope Reclassified

$\mathrm{T}(\mathrm{Re})$ : Temperature Reclassified

After standardizing and filtering the data, yielded the following patterns: low-risk (R1), medium-risk (R2), high-risk (R3), and very high-risk (R4), as shown in Figure 2.

\section{Results and Discussion}

The Earth's climate is subject to constant change, great human invasions recorded in history was strongly given the occurrence of weather phenomena, which is no different to the many species of animals and concomitantly many of their parasites. So climate change can be understood as any change in climate over the years due to natural variability or as a result of human activity in a way that creates some discomfort for many organisms with greater or lesser intensity, favoring or harming in many cases its permanence and survival. Thus, seasonal climatic fluctuations can produce effects on the dynamics of vector-borne tropical diseases (BARCELLOS et al., 2009).

In relation to bovine fasciolosis, a disease transmitted by water snails of the genus Lymnaea, even subtle changes in temperature and precipitation may favor somewhat the spread of the disease, since the intermediate host of $F$. hepatica, benefits immediately with increasing the number of waterbody available. However, the complexity existing in the host-parasite relationships and your environment must be considered as risk maps generated using Geographic Information Systems are powerful tools for future practical recommendations to be used in strategies for control and prevention of fasciolosis in order to contribute effectively reducing the losses caused to livestock.

Where: 
Figure 2. Flowchart representing the steps undertaken to develop cartographic maps for forecasting future fasciolosis risk in Feníritn Sants ctate Rrazil

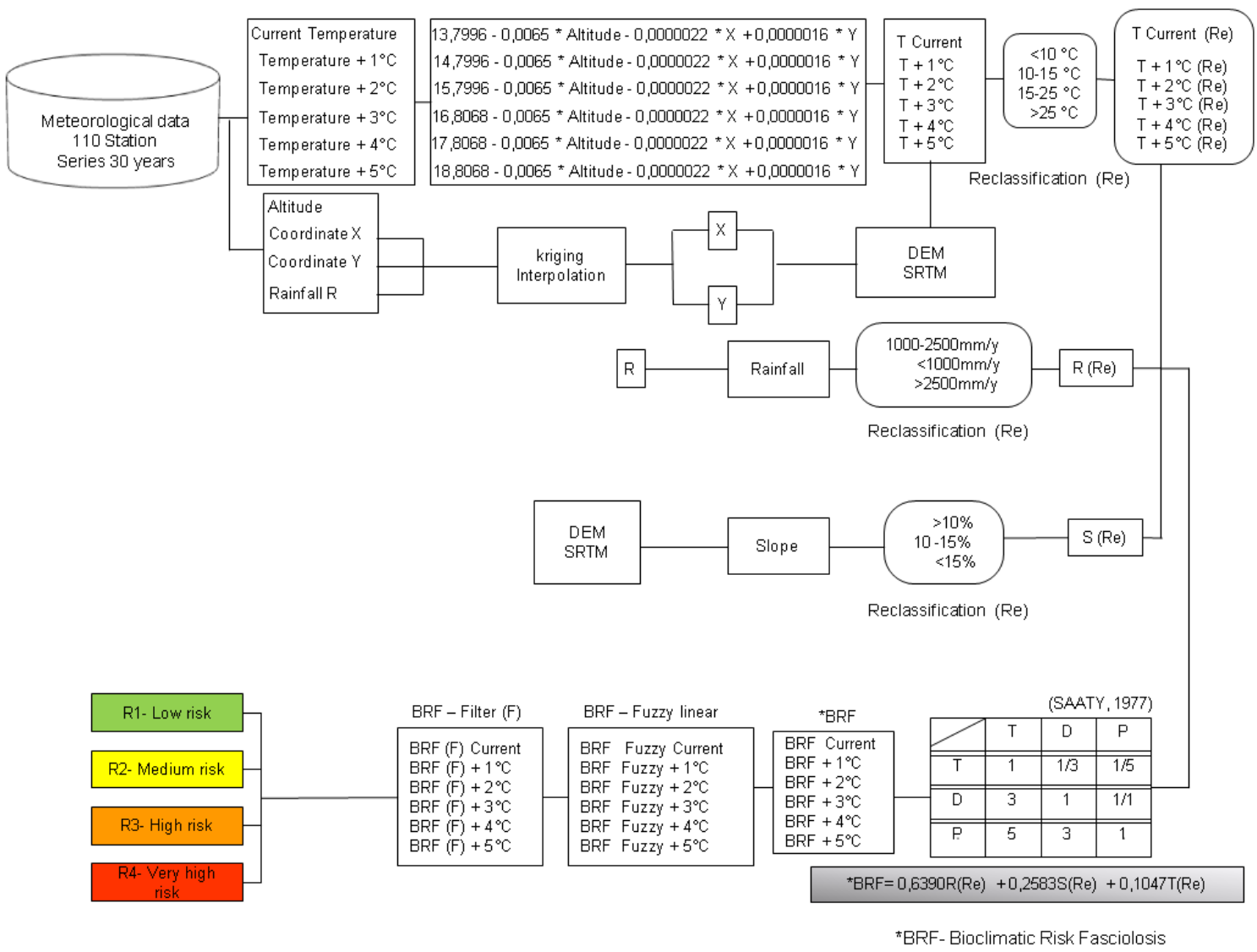

Source: Elaboration of the authors.

Thus, the current BRF showed that of the 78 municipalities contained in the total length of the state, $35.42 \%$ were entered in the class of very high risk for fasciolosis (R4) and $24.65 \%$ in low-risk class (R1) as show in Figure 3. It is noteworthy that the high-risk areas were generated based on suitable areas shown in Table 1. According to Dutra et al. (2010), most of the municipalities included in the high-risk category were found in areas where the slope values reached up to $10 \%$ and at altitudes of up to $500 \mathrm{~m}$. These results highlight the importance of slope as a risk factor for fasciolosis because lower slopes lead to lower water flow velocities, which result in constantly flooded areas. These areas are a factor that is directly related to the maintenance of Lymnaea snail populations, which act as intermediate hosts for the Fasciola hepatica parasite (DE WAAL et al., 2007; PAZ-SILVA et al., 2007).

In this context, Freitas et al. (2012) conducted a study in an area with the presence of snails of the genus Lymnaea located in the Alegre city, and using variables such as waterbody, slope, floodplains and grasslands, generate vulnerability maps for the occurrence of the disease and attributed all sites sampled in areas of greatest vulnerability risk, with percentages ranging $25-31 \%$. In another study, Freitas et al. (2014) observed through a zoning distribution for risk areas for fasciolosis that $52.24 \%$ of the entire state is in areas at risk for occurrence and survival of F. hepatica.

The Southern Espírito Santo is an area notoriously known for incidence of bovine 
fasciolosis. In a study by Bernardo et al. (2011) with data from a slaughterhouse in the Atilio Vivácqua city, 27.625 livers were condemned due to fasciolosis, representing a prevalence of $24.89 \%$ between the years 2006 to 2009 . Freitas et al. (2014) also found high percentages of prevalence, being recorded mainly in the southern region of the state, with percentages ranging from 0.01 to $28.41 \%$. Alves et al. (2011) observed in 717 stool specimens collected on properties in the region a cumulative frequency of $21.33 \%$ positive for disease cases. These data demonstrate the serious problems that fasciolosis leads on local production and highlight the importance of generating risk maps for disease.

Regarding the data of temperature and precipitation, there are locations where the current temperatures are above the limiting range for $F$. hepatica survival. But when these locations are combined with a high rainfall site, they will tend to tolerate future changes in risk patterns because the rain factor alone cannot be considered restrictive (FOX et al., 2011).

However, Rapsch et al. (2008) observed that in addition to the temperature and rainfall factors, others factors, such as moisture and soil conditions, have similar effects on $F$. hepatica survival. In this sense, not even the temperature factor alone can be considered limiting to the parasite or the development of its host. In the present study, we noted that areas that present the highest risks for disease transmission are located precisely in regions with average temperatures that are suitable for the development of the parasite and its intermediate hosts, which proves the correctness of the model.

It is known that increases in average global temperatures can directly influence the rainfall rates in certain regions. The effects of temperature and rainfall on the free-living stages of the parasite could potentially determine the abundance of the parasite load in certain animals, due to changes in regional climate conditions. Van Dijk et al. (2008) found clear evidence that gradual increases in average temperatures could influence the seasonal abundance and spatial distribution of various parasites throughout the UK. Durr et al. (2005) also found evidence of a relationship between increased temperatures (and subsequently increased rainfall) and the progression of fasciolosis prevalence in Melbourne, Australia.

Several studies on predicting the risk for fasciolosis have been undertaken in various regions worldwide. Many studies have suggested an increased risk for future disease, which is attributed to possible climate change (VAN DIJK et al., 2008; MAS-COMA et al., 2009).

The present study differs from the findings mentioned above because the data on fasciolosis indicated a decrease in the high-risk (R3) and very high-risk (R4) areas and an increase in low-risk areas (R1), as shown in Table 2.

Table 2. Description of the forecasted percentages by area according to risk classes and their respective temperature increases from $1^{\circ} \mathrm{C}$ to $5^{\circ} \mathrm{C}$ for Espírito Santo state, Brazil.

\begin{tabular}{ccccccc}
\hline Risk classes & ${ }^{1}$ Current BRF & $\begin{array}{c}{ }^{1} \mathrm{BRF} \\
+1{ }^{\circ} \mathrm{C}\end{array}$ & $\begin{array}{c}{ }^{1} \mathrm{BRF} \\
+2{ }^{\circ} \mathrm{C}\end{array}$ & $\begin{array}{c}{ }^{1} \mathrm{BRF} \\
+3{ }^{\circ} \mathrm{C}\end{array}$ & $\begin{array}{c}{ }^{1} \mathrm{BRF} \\
+4{ }^{\circ} \mathrm{C}\end{array}$ & $\begin{array}{c}{ }^{1} \mathrm{BRF} \\
+5^{\circ} \mathrm{C}\end{array}$ \\
\hline R1 Low-risk & 24.65 & 21.49 & 23.73 & 25.14 & 26.59 & 28.26 \\
R2 Medium-risk & 25.15 & 29.60 & 27.66 & 26.40 & 25.18 & 23.73 \\
R3 High-risk & 14.78 & 14.80 & 14.61 & 14.50 & 14.34 & 14.16 \\
R4 Very high-risk & 35.42 & 34.12 & 33.99 & 33.96 & 33.89 & 33.84 \\
\hline
\end{tabular}

${ }^{1}$ BRF: Bioclimatic risk for Fasciola hepatica (Linnaeus, 1758).

Source: Elaboration of the authors. 
Thus, it is possible to observe that a temperature increase of $5^{\circ} \mathrm{C}$ favors a decrease from $35.42 \%$ to $33.84 \%$ in the very high-risk areas in the coastal regions and an increase from $24.65 \%$ to $28.26 \%$ in the low-risk areas throughout Espírito Santo state, Brazil (Figures 3 to 8).

Fox et al. (2011) found an unprecedented change for fasciolosis in the UK, in places where high temperatures were combined with low rainfall, may reflect a reduction in the risk for bovine fasciolosis by the year 2040. This possible reduction in areas R3 and R4 can be explained by the fact that rising temperatures in certain regions favor higher evaporation and transpiration rates in areas that are commonly flooded during the rainy seasons. It is known that high temperatures will lead to reduced moisture and consequently fewer wetlands (CRUZMENDOZA et al., 2005; FUENTES et al., 2006).

This factor is considered important because these areas are fundamental for the development of Lymnaea snails and also for the survival of the larval forms of F. hepatica (TUM et al., 2004; FUENTES et al., 2006; DE WAAL et al., 2007; BENNEMA et al., 2011).

Rising temperatures may also limit the areas of livestock grazing, leading to a possible decreased risk of contamination to the flock. Regions where the grazing season may be reduced will lead to an increase in low-risk areas (R1), because according to Bennema et al. (2011) in proportion to food shortages coupled with the reduction of the length of the grazing season, can influence directly the contamination of the animals by metacercariae, which are the infective stage of the parasite encysted.

The time pasture can also be considered a risk factor, because animals who spend long periods feeding are subject to greater exposure due to the presence of metacercariae from the environment (KANTZOURA et al., 2011).

Increasing temperatures may also limit the areas that are available for livestock grazing, which will lead to an eventual decreased risk of contamination in herds. An increase in the number of regions where the grazing season is reduced will lead to an increase in low-risk areas (R1). According to Bennema et al. (2011), food shortages that are coupled with a reduced duration of the grazing season can directly influence animals contaminated by metacercariae, which is the parasite's infective encysted stage.

The amount of time spent on pasture lands can also be considered to be a risk factor because animals that spend long periods feeding are subject to more exposure due to the presence of metacercariae that have been deposited in the environment from the feces of animals that are contaminated by the parasite (KANTZOURA et al., 2011). In this context, Rapsch et al. (2008) classified risk according to the temperature of the environment in which the eggs were discovered and found that there was a potential temperature threshold for $F$. hepatica egg survival. These findings suggest that the risk tends to slowly decrease for temperatures above $25^{\circ} \mathrm{C}$, and in areas where the temperatures reach $30^{\circ} \mathrm{C}$ or more, there will be a rapid negative trend in the risk for each increased degree in the temperature. 
Figure 3. Risk map for fasciolosis in Espírito Santo state, Brazil, representing the current risk.

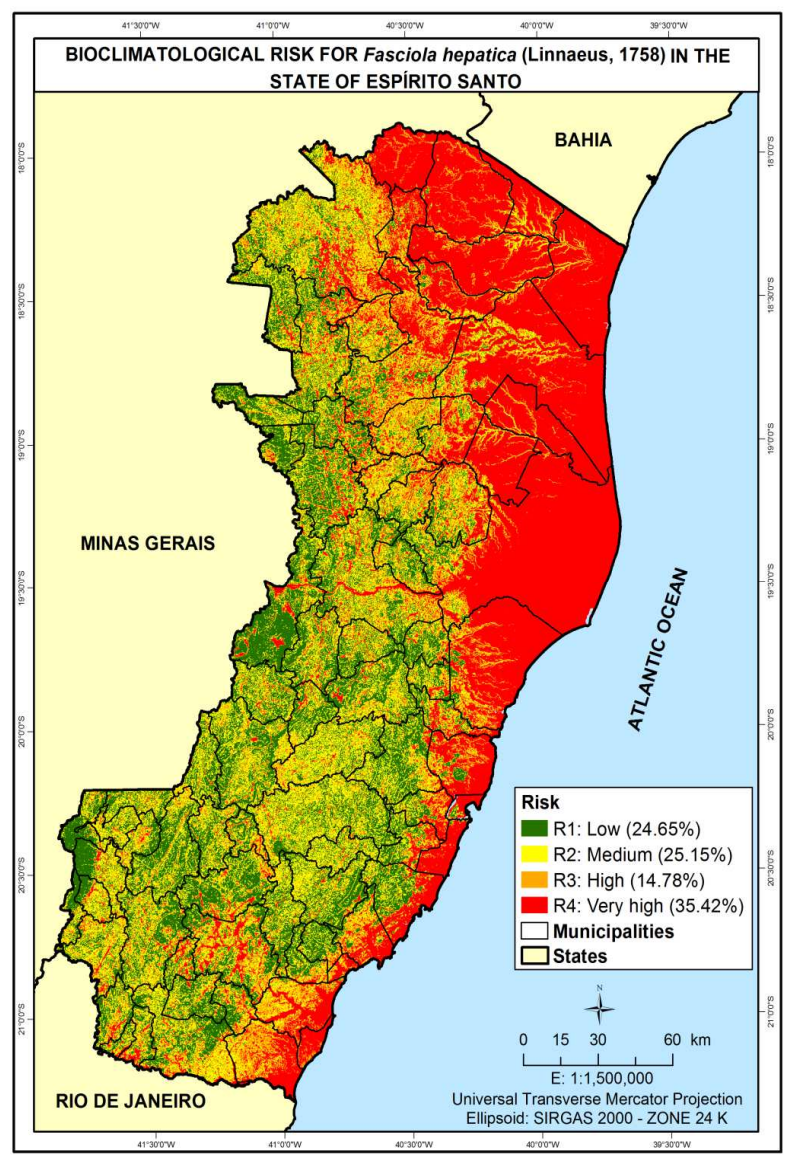

Source: Elaboration of the authors.
Figure 4. Risk map for fasciolosis in Espírito Santo state, Brazil, representing the predicted risk after temperature increases of $1^{\circ} \mathrm{C}$.

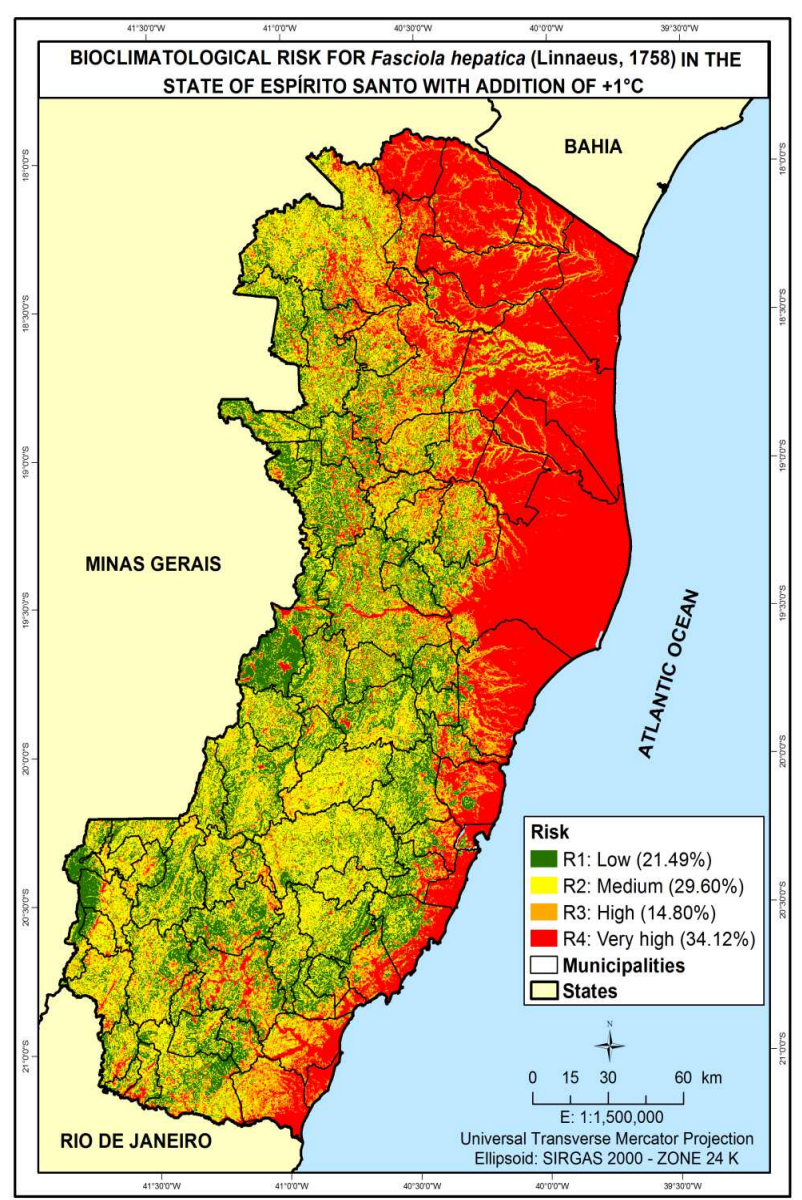

Source: Elaboration of the authors. 
Figure 5. Risk map for fasciolosis in Espírito Santo state, Brazil, representing the predicted risk after temperature increases of $2^{\circ} \mathrm{C}$.

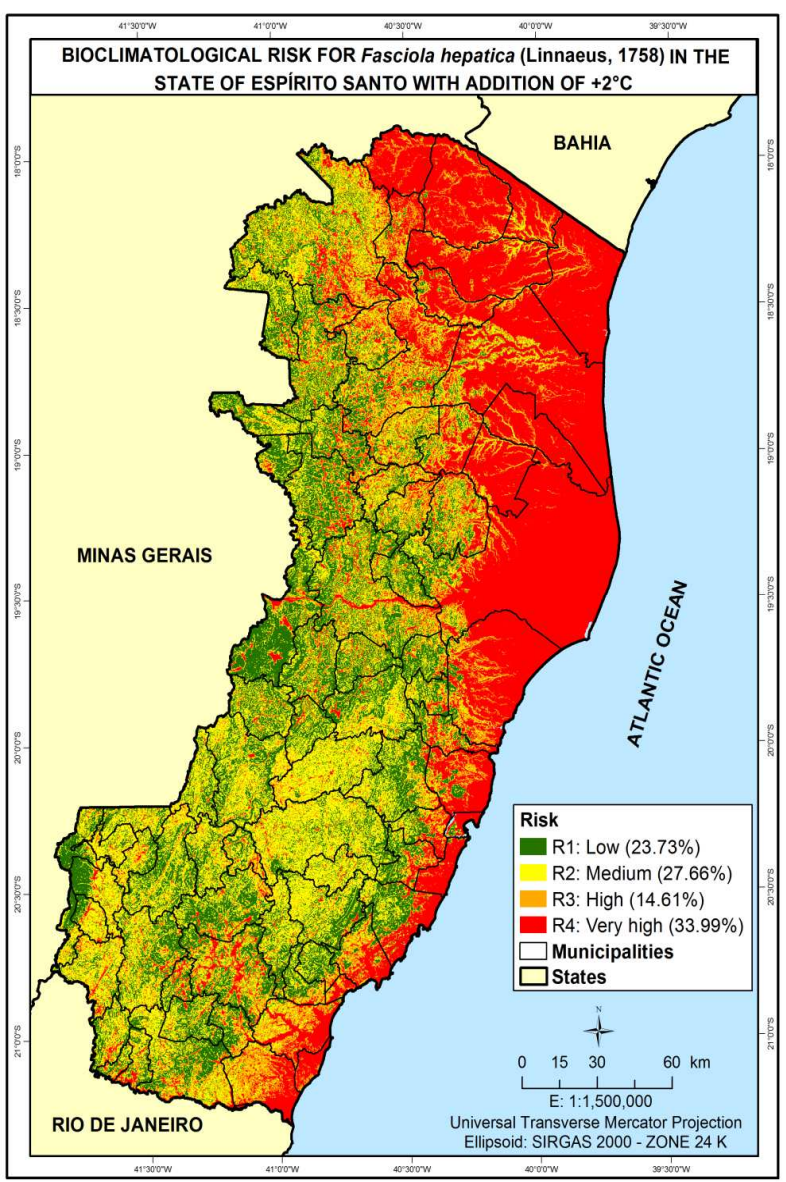

Source: Elaboration of the authors.
Figure 6. Risk map for fasciolosis in Espírito Santo state, Brazil, representing the predicted risk after temperature increases of $3^{\circ} \mathrm{C}$.

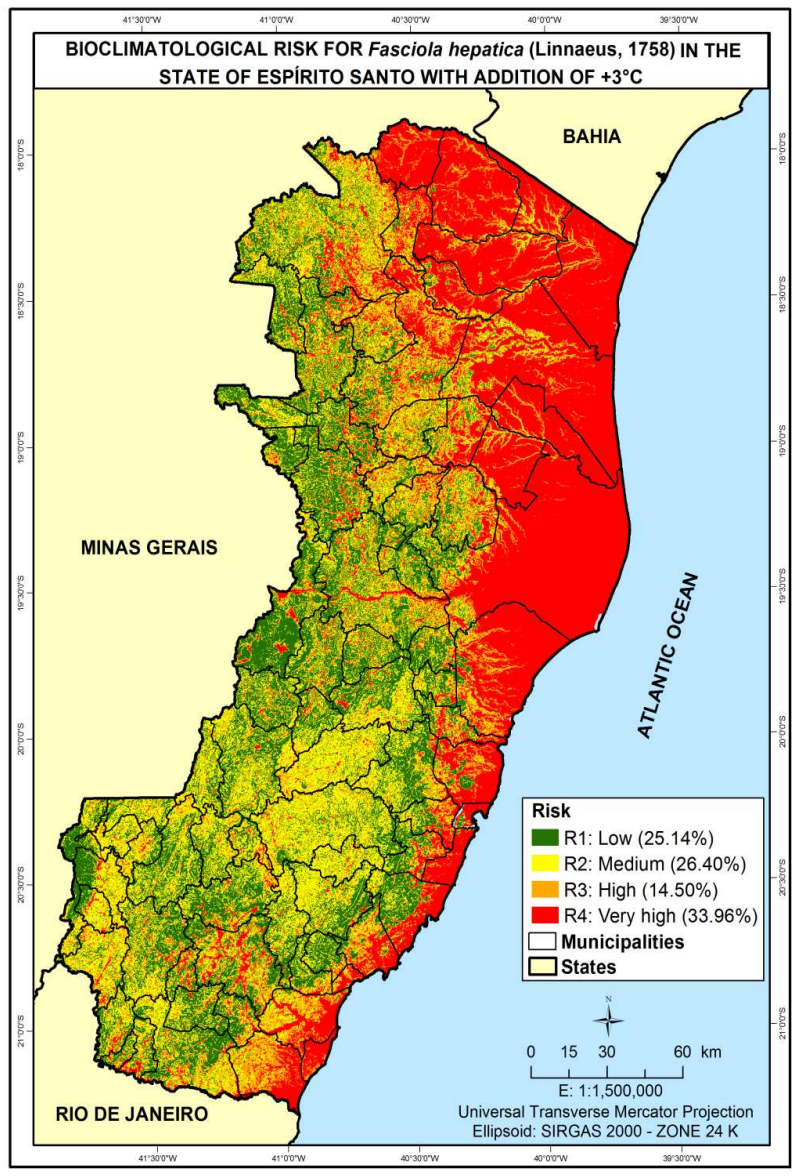

Source: Elaboration of the authors. 
Figure 7. Risk map for fasciolosis in Espírito Santo state, Brazil, representing the predicted risk after temperature increases of $4^{\circ} \mathrm{C}$.

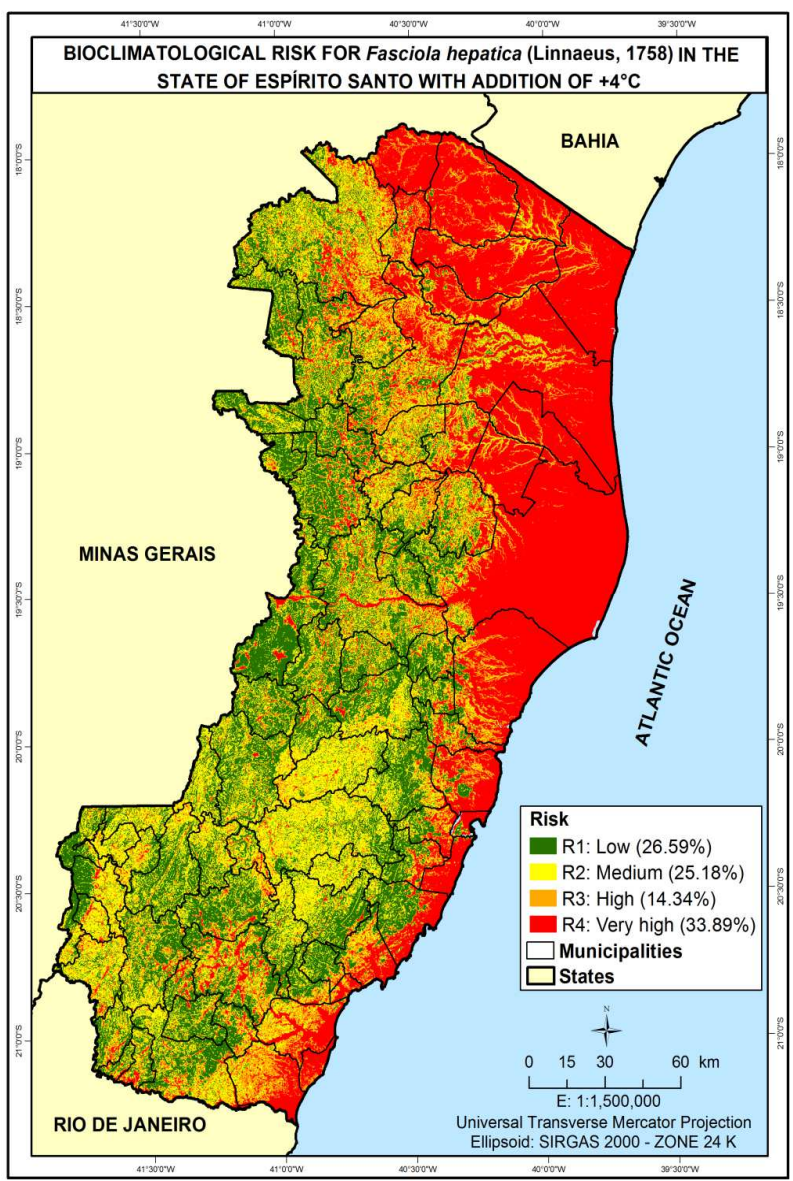

Source: Elaboration of the authors.

Although the results exhibited fewer areas of risk for F. hepatica in Espírito Santo state, Brazil, given the possible effects of climate change, these findings only reflect the trends predicted by the future forecast model. However, the risk maps generated in this study provide a valuable tool for controlling and reducing the risk of fasciolosis. It is also noteworthy that other factors must be involved in these predictions, including differences between current and temporal scales, possible anthelmintic drug resistance, the acclimation of parasites or their hosts over time, and their interactions with the environment.
Figure 8. Risk map for fasciolosis in Espírito Santo state, Brazil, representing the predicted risk after temperature increases of $5^{\circ} \mathrm{C}$.

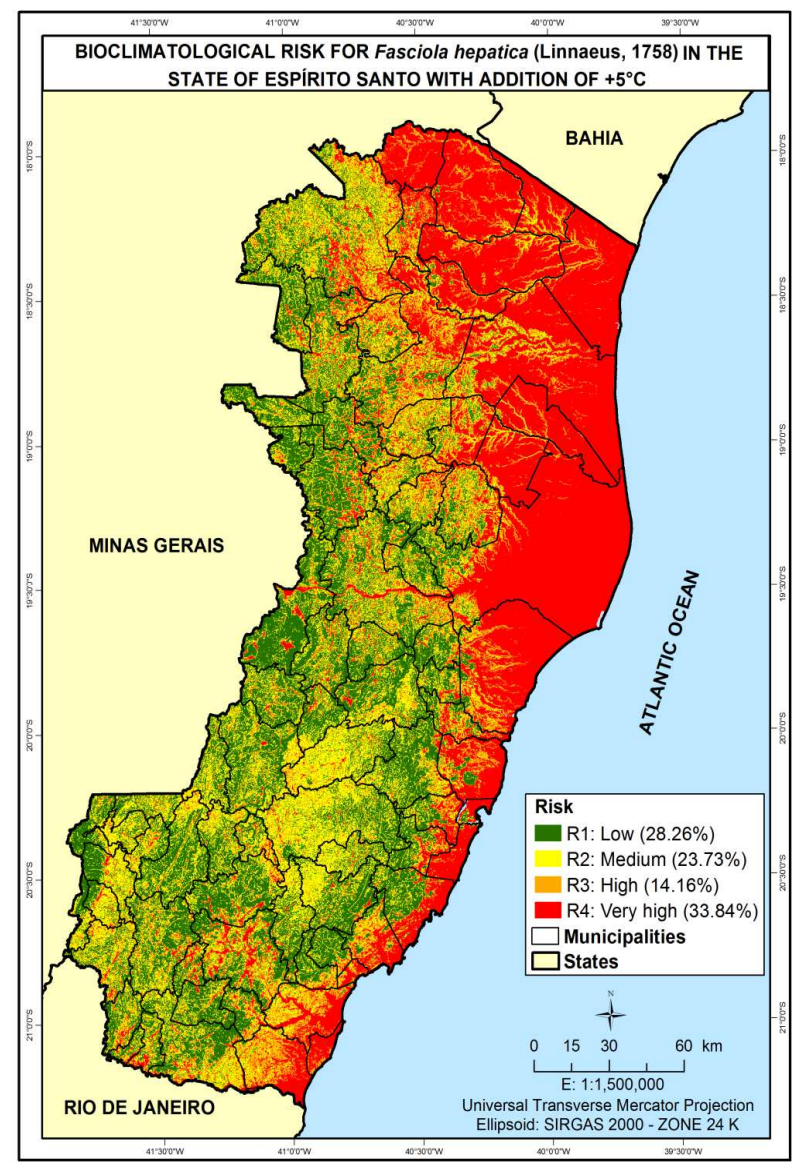

Source: Elaboration of the authors.

\section{Acknowledgments}

The Coordenação de Aperfeiçoamento de Pessoal de Nível Superior-CAPES, supported by the project (Procad 093/2007) and the Fundação de Amparo a Pesquisa do Espírito Santo-FAPES (FAPES proc. $N^{\circ}$. 54695244). The Institute of Agricultural and Forestry Defense of the Espírito Santo (IDAF) and Superintendent of the Federal Ministry of Agriculture in the Espírito Santo (MAPA-ES). 


\section{References}

ALVES, D. P.; CARNEIRO, M. B.; MARTINS, I. V. F.; BERNARDO, C. C.; DONATELE, D. M.; PEREIRA, J. O. S.; ALMEIDA, B. R.; AVELAR, B. R.; LEÃO, A. G. C. Distribution and factors associated with Fasciola hepatica infection in cattle in the south of Espírito Santo State, Brazil. The Journal of Venomous Animals and Toxins Including Tropical Diseases, Botucatu, v. 17, n. 3, p. 271-276, 2011.

BARCELLOS, C.; MONTEIRO, A. M. V.; CORVALÁN, C.; GURGEL, H. C.; CARVALHO, M. S.; ARTAXO, P.; HACON, S.; RAGONI, V. Mudanças climáticas e ambientais e as doenças infecciosas: cenários e incertezas para o Brasil. Epidemiologia e Serviços de Saúde, Brasília, v. 18, n. 3, p. 285-304, 2009.

BENNEMA, S. C.; DUCHEYNE, E.; VERCRUYSSE, J.; CLAEREBOUT, E.; HENDRICKX, G.; CHARLIER, J. Relative importance of management, meteorological and environmental factors in the spatial distribution of Fasciola hepatica in dairy cattle in a temperate climate zone. International Journal for Parasitology, Oxford, v. 41, n. 2, p. 225-233, 2011.

BERNARDO, C. C.; CARNEIRO, M. B.; AVELAR, B. R.; DONATELE, D. M.; MARTINS, I. V. F.; PEREIRA, M. J. S. Prevalence of liver condemnation due to bovine fasciolosis in Southern Espírito Santo: temporal distribution and economic losses. Revista Brasileira de Parasitologia Veterinária, São Carlos, v. 20, n. 1, p. 4953, 2011

CRUZ-MENDONZA， I.; VELARDE-IBARRA， F.; QUINTERO-MARTÍNEZ, M. T.; NARANJO-GRACÍA, E.; LECUMBERRI-LÓPEZ, J.; CORREA, D. Seasonal transmission of Fasciola hepatica in cattle and Lymnaea (Fossaria) humilis snails in central Mexico. Parasitology Research, Berlin, v. 95, n. 4, p. 283-286, 2005.

CUNHA, F. O. V.; MARQUES, S. M. T.; MATTOS, M. J. T. Prevalence of slaughter and liver condemnation due to Fasciola hepatica among sheep in the state of Rio Grande do Sul, Brazil 2000 and 2005. Parasitología Latinoamericana, Santiago, v. 62, n. 3-4, p. 188-191, 2007.

DE WAAL, T.; RELF, V.; GOOD, B.; GRAY, J.; MURPHY, T.; FORBES, A.; MULCAHY, G. Developing Models For The Prediction of Fasciolosis in Ireland. In: HOLDEN, N. M.; HOCHSTRASSER, T.; SCHULTE, R. P. O.; WALSH, S. (Ed.). Making Science Work on the Farm, A Workshop on Decision Support Systems for Irish Agriculture. Dublin, Ireland: Agmet, 2007. p. 60-63.

DURR, P. A.; TAIT, N.; LAWSON, A. B. Bayesian hierarchical modelling to enhance the epidemiological value of abattoir surveys for bovine fasciolosis. Preventive Veterinary Medicine, Colorado, v. 71, n. 3-4, p. 157-172, 2005.

DUTRA, L. H.; MOLENTO, M. B.; NAUMANN, C. R. C.; BIONDO, A. W.; FORTES, F. S.; SAVIO, D.; MALONE, J. B. Mapping risk of bovine fasciolosis in the south of Brazil using geographic information systems. Veterinary Parasitology, Amsterdam, v. 169, n. 1-2, p. 76-81, 2010.

FOX, N. J.; MARION, G.; DAVIDSON, R. S.; WHITE, P. C. L.; HUTCHINGS, M. R. Livestock helminths in a changing climate: approaches and restrictions to meaningful predictions. Animals, Cambridge, v. 2, n. 1, p. 93-107, 2012.

FOX, N. J.;WHITE, P.C.L.; MCCLEAN, C. J.; MARION, G.; EVAN, A.; HUTCHINGS, M. R. Predicting impacts of climate change on Fasciola hepatica risk. Plos One, Cambridge, v. 6, n. 1, p. 16-26, 2011.

FREITAS, D. F.; MARTINS, I. V. F.; SANTOS, G. M.; SANTOS, A. R.; GOMES, D. S. Bioclimatic distribution and prevalence maps for Fasciola hepatica in Epirito Santo State, Brazil. The Journal of Venomous Animals and Toxins Including Tropical Diseases, Botucatu, v. 20, n. 1, p. 32, 2014.

FREITAS, D. F.; MARTINS, I. F. V.; TULER, V.; SANTOS, G. M. A.; SANTOS, A. R. Vulnerabilidade para a ocorrência de fasciolose na área experimental do Instituto Federal de Educação, Ciência e Tecnologia do Espírito Santo, IFES, Alegre, ES. Arquivos do Instituto Biológico, São Paulo, v. 79, n. 4, p. 533-540, 2012.

FUENTES, M. V. Proposal of a geographic information system for modeling zoonotic fasciolosis transmission in the Andes. Parasitología latinoamericana, Santiago, v. 59, n. 1-2, p. 51-55, 2004.

Remote sensing and climate data as a key for understanding fasciolosis transmission in the Andes: review and update of an ongoing interdisciplinary project. Geospatial Health, Estocolmo, v. 1, n. 1, p. 59-70, 2006.

FUENTES, M. V.; SAINZ-ELIPE, S.; NIETO, P.; MALONE, J. B.; MAS-COMA, S. Geographical information systems risk assessment models for zoonotic fasciolosis in the South American Andes region. Parassitologia, Roma, v. 47, n. 1, p. 151-156, 2005.

HOPE-CAWDERY, M. M. J.; TALUNTAIS, A. F.; LEITRIM, C. Changing temperatures and prediction models for the liver fluke (Fasciola hepatica). Journal of Thermal Biology, Oxford, v. 6, n. 1, p. 403-408, 1981. 
INTERGOVERNMENTAL PANEL ON CLIMATE CHANGE - IPCC. Climate change. The physical science basis. Contribution of working group I to the fourth assessment report of the IPCC. Cambridge: Cambridge University Press, 2007. Available at: <http//www.ipcc. ch/ipccreports/ar4-wg1.htm>. Accessed at: 3 aug. 2012.

KANTZOURA, V.; KOUAM, M. K.; DEMIRIS, N.; FEIDAS, H.; THEODOROPOULOS, G. Risk factors and geospatial modelling for the presence of Fasciola hepatica infection in sheep and goat farms in the Greek temperate Mediterranean environment. Parasitology, Cambridge, v. 138, n. 1, p. 926-938, 2011.

KENYON, F.; SARGISON, N. D.; SKUCE, P. J.; JACKSON, F. Sheep helminth parasitic disease in south eastern Scotland arising as a possible consequence of climate change. Veterinary Parasitology, Amsterdam, v. 163, n. 4, p. 293-297, 2009.

MALONE, J. B.; FEHLER, D. P.; LOYACANO, A. F.; ZUKOWSKI, S. H. Use of Landsat MSS imagery and soil type in a geographical information system to assess site specific risk of Fasciola hepatica on Red river basin farms in Louisiana. Annals of the New York Academy of Sciences, Nova Iorque, v. 653, n. 1, p. 389-397, 1992.

MARTINS, I. V. F.; AVELAR, B. R.; PEREIRA, M. J. S.; FONSECA, A. H. Application of a geographical information system approach for risk analysis of fascioliasis in southern Espírito Santo state, Brazil. Geospatial Health, Estocolmo, v. 3, n. 3, p. 87-93, 2012.

MAS-COMA, S.; FUNATSU, I. R.; BARGUES, M. D. Fasciola hepatica and lymnaeid snails occurring at very high altitude in South America. Parasitology, Cambridge, v. 123, n. 7, p. 115-127, 2001.

MAS-COMA, S.; VALERO, M. A.; BARGUES, M. D. Climate change effects on trematodiases, with emphasis on zoonotic fascioliasis and schistosomiasis. Veterinary Parasitology, Amsterdam, v. 163, n. 4, p. 264-280, 2009.

MCCANN, C. M.; BAYLIS, M.; WILLIAMS, D. J. L. The development of linear regression models using environmental variables to explain the spatial distribution of Fasciola hepatica infection in dairy herds in England and Wales. International Journal of Parasitology, Philadelphia, v. 40, n. 9, p. 1021-1028, 2010.

MITCHELL, G. B. B. Treatment and control of liver fluke in sheep and cattle. Edimburgo: Technical Note 557, nov. 2003. 8 p.

OLLERENSHAW, C. B.; ROWLANDS, W. T. A method of forecasting the incidence of fascioliasis in Anglesey. Veterinary Record, London, v. 17, n. 1, p. 591-598, 1959.
PAZ-SILVA, A.; HILLYER, G. V.; ARIAS, M. S.; SÁNCHEZ-ANDRADE, R.; PEDREIRA, J.; SUÁREZ, J. L.; LOMBA, C.; DÍAZ, P.; FRANCISCO, I.; DÍEZBAÑOS, P.; MORRONDO, P. A cross-sectional study of fasciolosis in autochthonous cattle from NW Spain by using a $2.9-\mathrm{kda}$ recombinant protein. International Journal of Applied Research in Veterinary Medicine, v. 5, n. 2, p. 52-56, 2007.

RAPSCH, C.; DAHINDEN, T.; HEINZMANN, D.; TORGERSON, P. R.; BRAUN, U.; DEPLAZES, P.; HURNI, L.; BAR, H.; KNUBBEN-SCHWEIZER, G. An interactive map to assess the potential spread of Lymnaea truncatula and the free-living stages of Fasciola hepatica in Switzerland. Veterinary Parasitology, Amsterdam, v. 154, n. 3, p. 242-249, 2008.

SAATY, T. L. A. Scaling method for priorities in hierarchical structures. Journal of Mathematical Psychology, Philadelphia, v. 15, n. 3, p. 234-281, 1977.

SIMSEK, S.; UTUK, A. E.; BALKAYA, I. Molecular differentiation of Turkey cattle isolates of Fasciola hepatica and Fasciola gigantic. Helminthologia, Bratislava, v. 48, n. 1, p. 3-7, 2011.

SILVA, E. D.; SANTOS, A. R.; SILVA, K. G. Estudo morfológico e climático dos municípios da região Serrana do Estado do Espírito Santo. Caminhos de Geografia, Uberlânida, v. 12, n. 39, p. 94-103, 2011.

THORNTHWAITE, C. W.; MATTER, J. R. The water balance. New Jersey Centerton: Publications in Climatology, 1955. 104 p.

TUM, S.; PUOTINEN, M. L.; COPEMAN, D. B. A geographic information systems model for mapping risk of fasciolosis in cattle and buffaloes in Cambodia. Veterinary Parasitology, Amsterdam, v. 122, n. 2, p. 141149, 2004.

VAN DIJK, J.; DAVID, G. P.; BAIRD, G.; MORGAN, E. R. Back to the future: developing hypotheses on the effects of climate change on ovine parasitic gastroenteritis from historical data. Veterinary Parasitology, Amsterdam, v. 158, n. 1-2, p. 73-84, 2008.

VIANELLO, R. L.; ALVES, A. R. Meteorologia básica e aplicações. Viçosa: Editora UFV, 1991. 450 p.

WALKER, S. M.; JOHNSTON, C.; HOEY, E. M.; FAIRWEATHER, I.; ORGSTEEDE, F. B.; GAASENBEEK, C.; PRODÖHL, P. A.; TRUDGETT, A. Population dynamics of the liver fluke, Fasciola hepatica: the effect of time and spatial separation on the genetic diversity of fluke populations in the Netherlands. Parasitologia, v. 138, n. 2, p. 215-223, 2011. 
YILMA, J. M.; MALONE, J. B. A geographic information system forecast model for strategic control of fasciolosis in Ethiopia. Veterinary Parasitology, Amsterdam, v. 78, n. 2, p. 103-127, 1998.

ZUKOWSK, S. H.; WILKERSON, G. W.; MALONE, J. B. Fasciolosis in cattle in Louisiana. II. Development of a system to use soil maps in a geographic information system to estimate disease risk on Louisiana coastal marsh rangeland. Veterinary Parasitology, Amsterdam, v. 47, n. 1-2, p. 51-65, 1993. 